\title{
Peningkatkan Hasil Belajar IPA melalui Model Pembelajaran Mind Mapping di SDN Ciater 03 Tangerang Selatan
}

\author{
Elma Silvia ${ }^{*}$ \\ ${ }^{1}$ STKIP Kusumanegara Jakarta. \\ Jln. Raya Bogor Km.24 Cijantung Jakarta Timur \\ * Corresponding Author: elmasilviateachersmart@gmail.com
}

\section{Info Artikel Abstract}

Sejarah Artikel:

Diterima: 03/03/2020

Direvisi: $10 / 03 / 2020$

Disetujui: 15/03/2020

Keywords: Learning Achievement, Mind Mapping
The background of this study is many students' learning outcomes less than minimal completeness criteria. The purpose of this study is to improve science learning outcomes of students on the material Outer Shape of Animal's Body and Plant and Its Function through Mind Mapping Learning Model in class IV students. The research method used was Classroom Action Research that followed the Kemmis \& Taggart model. This study includes 3 cycles; each cycle includes 4 stages, namely planning, acting, observing and reflecting. The results showed that there was a significant increase in science learning outcomes in grade IV students. It can be proved through the average results of natural science tests in each cycle that always increases. The average value achieved in cycle $I=70.30$; cycle $I I=$ 77.91; and cycle III = 80.09. The results of the interview can be concluded that learning science through Mind Mapping is fun for students. Thus it can be concluded overall that learning science using Mind Mapping method can improve students' learning outcomes in science.

\begin{abstract}
Abstrak
Latar belakang penelitian ini adalah sebagian besar siswa memiliki hasil belajar kurang dari standard Kriteria Ketuntasan Minimal (KKM). Tujuan Penelitian ini adalah untuk meningkatkan hasil belajar IPA peserta didik pada materi Bentuk Luar Tubuh Hewan dan Tumbuhan serta Fungsinya melalui Model Pembelajaran Mind Mapping pada peserta didik kelas IV. Metode penelitian yang digunakan adalah penelitian tindakan kelas yang mengikuti model Kemmis \& Taggart. Penelitian ini mencakup 3 siklus dimana masing-masing siklus mencakup 4 tahap yaitu planning (Perencanaan), acting (Pelaksanaan), observing (Observasi) dan reflecting (Refleksi). Hasil penelitian menunjukkan bahwa terjadi peningkatan hasil belajar IPA yang signifikan pada peserta didik kelas IV. Hal ini dibuktikan melalui hasil ratarata tes IPA pada setiap siklus yang selalu meningkat. Nilai rata-rata yang dicapai pada siklus I $=70,30$; siklus II = 77,91; dan siklus III = 80,09. Hasil wawancarapun dapat disimpulkan bahwa belajar IPA melalui Mind Mapping adalah menyenangkan bagi siswa. Dengan demikian dapat disimpulkan secara keseluruhan bahwa belajar IPA dengan menggunakan metode Mind Mapping dapat meningkatkan hasil belajar IPA siswa.
\end{abstract}

\section{"Alamat korespondensi:}

Program Studi Pendidikan Guru Sekolah Dasar STKIP Kusumanegara Jakarta

Jln. Raya Bogor Km.24 Cijantung Jakarta Timur, 13770

E-mail: elmasilviateachersmart@gmail.com
(C) 2020 Program Studi PGSD Universitas Flores Email: primagistrauniflor@ gmail.com 


\section{PENDAHULUAN}

Pendidikan adalah proses pembelajaran bagi peserta didik untuk dapat mengerti, paham, dan membuat manusia lebih kritis dalam berpikir. Pendidikan adalah pengalaman-pengalaman belajar terprogram dalam bentuk pendidikan formal, non formal dan informal dan luar sekolah yang berlangsung seumur hidup, bertujuan untuk mengoptimalisasi kemampuan-kemampuan individu. Peningkatan mutu pendidikan merupakan sasaran pembangunan disektor pendidikan nasional dan merupakan bagian integral dari upaya peningkatan kualitas manusia Indonesia secara menyeluruh. Undang-Undang No 20 Tahun 2003 pasal 3 menyatakan bahwa Pendidikan Nasional berfungsi mengembangkan kemampuan dan membentuk watak serta peradaban bangsa yang bermartabat dalam rangka mencerdaskan kehidupan bangsa, bertujuan untuk berkembangnya potensi peserta didik agar menjadi manusia yang beriman dan bertaqwa kepada Tuhan Yang Maha Esa, berakhlak mulia, sehat, berilmu, cakap, kreatif, dan mandiri.

Peserta didik dalam pembelajaran harus mengalami sendiri apa yang dipelajarinya. Proses belajar tidak hanya menghafal. Peserta didik harus membangun dan mengembangkan pengetahuan dipikirannya sendiri tanpa harus dipaksa sehingga pembelajaran akan menjadi bermakna.

Keberhasilan pendidikan dipengaruhi oleh beberapa faktor, diantaranya guru. Peranan guru adalah sebagai fasilitator, motivator yang mendukung keterlibatan Peserta didik dalam mengikuti kegiatan pembelajaran. Selain guru faktor yang turut mempengaruhi keberhasilan belajar adalah sarana dan prasarana pendukung pendidikan.

Kenyataan yang terjadi dalam proses belajar dan mengajar belum sesuai dengan apa yang diharapkan. Peserta didik seharusnya belajar dengan giat, tekun dan semangat pada saat proses pembelajaran, namun kenyataannya banyak peserta didik yang malas dan merasa bosan ketika proses pembelajaran dimulai. Mereka asik melakukan aktivitasnya sendiri, seperti mengobrol dengan Peserta didik yang lain, menggambar dan mencoretcoret kertas. Hal ini dipengaruhi cara guru menyampaikan materi di kelas dengan menggunakan metode ceramah. Penerapan teori behavioristik dan lebih suka menggunakan metode ceramah ini menyebabkan sebagian besar peserta didik memiliki motivasi yang rendah, kurang kreatif dalam menjawab pertanyaan dan lemah dalam menguasai materi.

Tugas seorang pendidik adalah memperhatikan kebutuhan Peserta didik bukan memaksakan kehendak yang membuat Peserta didik merasa kurang nyaman dalam menuntut ilmu. Guru belum mencoba metode pembelajaran yang mengaktifkan Peserta didik (student centered). Keterlibatan Peserta didik yang berperan aktif selama proses pembelajaran tentu sangat mempengaruhi pemahaman Peserta didik mengenai materi yang diajarkan. Permasalahan yang paling utama di SDN Ciater 03 Tangerang Selatan adalah motivasi, hasil belajar yang rendah dan kebanyakan guru masih menggunakan metode ceramah karena dianggap lebih mudah menyampaikan materi.

Berdasarkan hasil dengan guru untuk materi Hewan dan Tumbuhan di Lingkungan Rumahku, banyak Peserta didik yang belum mencapai kriteria ketuntasan minimal (KKM). Kriteria ketuntasan minimal di sekolah adalah 70. Dari hasil belajar Peserta didik tahun sebelumnya dapat dilihat bahwa dari 34 peserta didik, hanya sekitar 7 peserta didik $(30,43 \%)$ yang berhasil mencapai nilai KKM pada materi hewan dan tumbuhan di lingkungan rumahku. Nilai rata-rata yang dicapai kelas 60,22 masih rendah dan belum memenuhi standar nilai KKM yang telah ditentukan yaitu 70 .

Rendahnya pencapian KKM pada materi Hewan dan Tumbuhan di Lingkungan Rumahku disebabkan karena penggunaan metode pembelajaran yang kurang variatif sehingga motivasi dan semangat belajar dalam pembelajaran menjadi rendah yang berdampak pada hasil belajar.

Kemajuan ilmu pengetahuan dan
teknologi menuntut pengembangan
kemampuan peserta didik Sekolah Dasar
dalam bidang ilmu pengetahuan. Salah satunya
adalah mata pelajaran IPA. Hal ini sangat
dibutuhkan Peserta didik untuk melanjutkan
belajar ke jenjang yang lebih tinggi,


mengembangkan bakat dan minat serta adaptasi dengan lingkungan. Melatih keterampilan Peserta didik untuk berpikir secara kreatif dan inovatif melalui IPA, merupakan pelatihan awal bagi Peserta didik untuk berpikir kritis dalam meningkatkan motivasi Peserta didik dalam belajar IPA. Sehubungan dengan hal tersebut, pengajaran mata pelajaran IPA hendaknya menekankan pembelajaran Peserta didik aktif melalui berbagai macam strategi.

Proses pembelajaran di kelas memerlukan strategi yang tepat. Penggunaan strategi yang kurang tepat akan menghambat pencapaian tujuan pembelajaran yang diinginkan. Beberapa strategi pembelajaran, terdapat strategi yang menarik dan dapat memicu keterlibatan Peserta didik secara aktif dalam kegiatan belajar mengajar yaitu suatu pembelajaran yang melibatkan Peserta didik secara aktif baik mental maupun fisik. Salah satu strategi pembelajaran aktif yang dapat memotivasi dan mengajak Peserta didik untuk terlibat langsung dalam proses belajar mengajar adalah model pembelajaran Mind Mapping.

Hasil belajar adalah kemampuan yang diperoleh anak setelah melalui kegiatan belajar (Jihad dalam Suwardi, dkk, 2014). Hasil belajar adalah pola-pola perbuatan, nilai-nilai, pengertian-pengertian, sikap-sikap, apresiasi dan keterampilan. Hasil belajar dapat diperoleh dengan melakukan evaluasi yang merupakan tindak lanjut cara untuk mengukur penguasaan peserta didik. Hasil belajar termasuk komponen pendidikan yang harus disesuaikan dengan pendidikan, karena hasil belajar diukur untuk mengetahui ketercapaian tujuan pendidikan melalui proses belajar mengajar.

Menurut pemikiran Gagne, hasil belajar berupa:

1) Informasi verbal adalah kapabilitas untuk mengungkapkan pengetahuan dalam bentuk bahasa, baik lisan maupun tertulis.

2) Keterampilan intelekstual, adalah mempresentasikan konsep dan merupakan kemampuan melakukan aktivitas kognitif bersifat khas.
3) Siasat kognitif, adalah kemampuan menyalurkan dan mengarahkan aktivitas kognitifnya sendiri. Kemampuan ini meliputi penggunaan konsep dan kaidah dalam memecahkan msalah

4) Keterampilan motorik adalah kemampuan melakuan serangkaian gerak jasmani dalam urutan dan koordinasi, sehingga terwujud otomatisme gerak jasmani.

5) Sikap adalah kemampuan dalam menerima/menolak obyek berdasarkan penilaian terhadap objek tersebut.

Sedangkan menurut Bloom (Nuning Apriani, Syahrial Ayub \& Hikmawati, 2016:127) hasil belajar mencakup kemampuan kognitif, afektif, dan psikomotorik. Domain kognitif adalah knowledge (pengetahuan, ingatan), comprehension (pemahaman, menjelaskan, meringkas, contoh) apllication (menerapkan), analysis (menguraikan, menentukan hubungan), synthesis (mengorganisasikan, merencanakan, membentuk bangunan baru) dan evaluation (menilai).

Domain afektif adalah receiving (sikap menerima), responding (memberikan respons), valuing (nilai), organization (organisasi), characterization (karakterisasi). Domain psikomotor meliputi initiatory, pre-routine, dan rountinized. Psikomotor juga mencakup keterampilan produktif, teknik, fisik, sosial, manajerial, dan intelektual. Sementara menurut Lindgren hasil pembelajaran meliputi kecakapan, informasi, pengetahuan, dan sikap.

Model pembelajaran adalah suatu cara atau jalan yang harus dilalui di dalam mengajar. Mengajar itu sendiri menurut Ulih dalam Slameto (2003:65) adalah menyajikan bahan pelajaran oleh orang kepada orang lain agar orang lain itu menerima, menguasai, dan mengembangkannya. Model mengajar yang kurang baik akan mempengaruhi proses dan hasil belajar peserta didik.

Model pembelajaran adalah suatu cara atau jalan yang harus dilalui dalam proses belajar, pembelajaran memiliki dua unsur penting yakni peserta didik dan guru. Bagi peserta didik model pembelajaran sangat 
penting dalam menentukan prestasi dan pengembangan potensi pribadi. Guru memiliki peranan penting dalam menerapkan model pembelajaran di kelas untuk mencapai tujuan belajar yang diinginkan.

Buzan (2004: 68) menyatakan Mind Mapping, yaitu cara yang paling mudah untuk memasukkan informasi kedalam otak dan untuk kembali mengambil informasi dari dalam otak. Mind Mapping merupakan teknik yang paling baik dalam membantu proses berpikir otak secara teratur karena menggunakan teknik grafis yang berasal dari pemikiran manusia yang bermanfaat untuk menyediakan kunci-kunci universal sehingga membuka potensi otak (Buzan dan Bary, 2004: 68)

Bahaudin (Fadillah, 2015) menyatakan bahwa Mind merupakan gagasan berbagai imajinasi. Mind merupakan suatu keadaan yang timbul bila otak (brain) hidup dan sedang bekerja. Lebih lanjut De Porter dan Hernacki (Fadillah, 2015) menjelaskan, peta pikiran merupakan teknik pemanfaatan keseluruhan otak dengan menggunakan citra visual dan prasarana grafis lainnya untuk membentuk suatu kesan yang lebih dalam.

Selanjutnya Sugiharto seperti yang dicitasi oleh Saputri \& Sungkono (2019) menyatakan bahwa mind Mapping adalah teknik meringkas bahan yang akan dipelajari dan memproyeksikan masalah yang dihadapi ke dalam bentuk peta atau teknik grafik sehingga lebih mudah memahaminya. Mind Mapping merupakan teknik visualisasi verbal ke dalam gambar.

Jensen dan Makowitz (2002) menjelaskan manfaat dari Mind Mapping dimana bertujuan membuat materi pelajaran terpola secara visual dan grafis yang akhirnya dapat membantu merekam, memperkuat, dan mengingat kemabli informasi yang telah dipelajari (Aji, 2016).

\section{METODE PENELITIAN}

Jenis penelitian dalam penelitian ini adalah penelitian tindakan kelas (Class Room Action Research). Penelitian tindakan kelas yaitu suatu pencermatan terhadap kegiatan yang sengaja dimunculkan, dan terjadi dalam sebuah kelas. Menurut Kemmis dan Mc Taggart "The approach is only action research when it is collaborative, through the critically examined action of individual group members" yang maknanya adalah dalam penelitian tindakan kelas diperlukan kolabolator, adalah orang yang mampu secara kritis memberi masukan pada saat penelitian melaksanakan tindakan dan pada tahap analisis dan refleksi.

Penelitian tindakan kelas dilaksanakan untuk meningkatkan proses pembelajaran. Pelaksanaannya dapat dibantu oleh kolabolator guna mencapai hasil yang diharapkan.

\section{HASIL DAN PEMBAHASAN}

\section{A. Hasil dan Pembahasan Siklus I}

Setiap siklus memiliki 3 aspek yang dibahas sesuai dengan tujuan penelitian tindakan kelas dan permasalahan yang terkandung dalam judul penelitian, yaitu pada aspek kualitas pembelajaran, keaktifan peserta didik dan hasil belajar peserta didik .

\section{a. Kualitas Pembelajaran}

Dalam Proses pelaksanaan pembelajaran siklus I ternyata dari dua kolaborator di peroleh hasil penelitian pelaksanaan pembelajaran yang tidak jauh berbeda, sehingga hasil rata-rata sebesar $76,54 \%$ dengan katagori berkualitas. Hasil tersebut banyak dipengaruhi oleh indikator yang belum terlaksana dengan baik,seperti indikator mengapersepsi materi sebelumnya yang memberikan ketuntasan belajar hanya 30,43\%, mengeksplorasi materi yang kurang jelas, terlalu banyak berbicara (lisan), penerapan model pembelajaran Mind Mappingyang belum efektif,media pembelajaran yang masih sederhana, dan komunikasi dengan peserta didik masih dalam proses penyesuaian iklim belajar pada masa lalu. Perbedaan penampilan peneliti dengan guru kelas jauh berbeda dari aspek penguasaan lingkungan belajar, pendekatan pembelajaran, gaya mengajarkan, dan aspek pedagogik lainnya. Proses pembelajaran dapat ditunjukan melalui gambar sebagai berikut: 




Gambar 1. Kegiatan Peserta Didik Saat mengurutkan kata pada siklus I

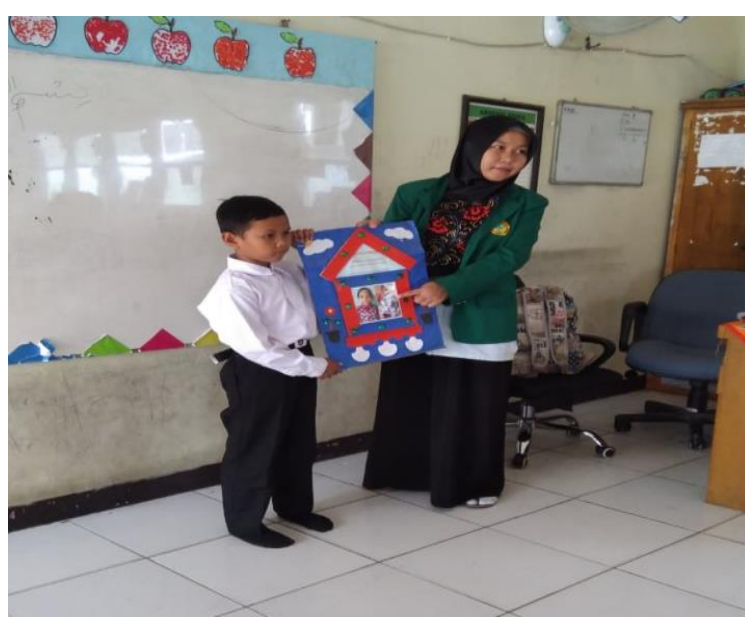

Gambar 2. Peserta didik yang Berhasil Mengurutkan Gambar

Ringkasan dari teori Zamroni mengemukakan bahwa kualitas proses pembelajaran merupakan bagaimana kondisi awal (input), yaitu kompetensi pedagogik dan profesional melalui suatu proses (process) untuk menghasilkan yang bermutu (output). Hal ini sangat nampak pada siklus I, dimana para peserta didik sebagai subjek penelitian (input) belum terbiasa menghadapi/menerima layanan dari peneiliti, begitu juga peneliti perlu penyesuaian diri (adaptation).

b. Motivasi Belajar dan Keaktifan Peserta Didik

Keaktifan belajar peserta didik berhubungan positif dengan motivasi belajar, sehingga pengumpulan datanya juga berbeda. Keaktifan belajar dapat di amati langsung dengan menggunakan lembar observasi, sedangkan motivasi belajar sulit diamati secara langsung, namun menggunakan angket.
Hasil motivasi belajar 23 peserta didik yang hadir diperoleh hasil motivasi belajar sebesar $71,48 \%$ dengan katagori baik. Nilai perolehan motivasi intrinsik sebesar 73,04\% lebih besar dari nilai perolehan motivasi ekstrinsik $69,91 \%$, tetapi tidak jauh berbeda, termasuk dengan nilai rata-rata motivasi belajar $71,48 \%$. Kondisi seperti ini merupakan hal wajar terjadi karena kehati-hatian dalam merespon apa yang terjadi selama proses pembelajaran.

Data keaktifan peserta didik siklus I dari dua kolaborator di peroleh hasil penelitian keaktifan peserta didik yang tidak jauh berbeda, sehingga hasil rata-rata sebesar 61,00\% dengan katagori aktif/baik.

\section{c. Hasil Belajar Peserta Didik}

Keadaan hasil belajar peserta didik kelas IV SD Negeri Ciater 03 sangat rendah dengan nilai rata-rata 60,22 dan ketuntasan hasil belajar $30,43 \%$. Keadaan ini sangat ironis bila dikaitkan dengan dua faktor utama yang mempengaruhi hasil belajar peserta didik yaitu faktor dari dalam diri peserta didik, diantaranya kecakapan, minat, bakat, usaha, motivasi perhatian, kelemahan dan kesehatan, serta kebiasaan peserta didik dan faktor dari luar diri peserta didik yang diantaranya lingkungan fisik dan non fisik, iklim belajar, lingkungan keluarga, lingkungan sosial budaya, serta lingkungan sekolah termasuk kualitas proses pembelajaran.

Faktor-faktor kondisi awal yang mempengaruhi hasil belajar maka dilakukan suatu pendekatan pembelajaran dengan model pembelajaran Mind Mappingsehingga diperoleh ketuntasan hasil belajar sebesar $78,26 \%$ tetapi belum mencapai kriteria keberhasilan yaitu minimal $80 \%$. Perubahan/perbaikan dari 30,43\% ke 78,26\% sudah baik, karena perbandingan tingkat kesukaran soal mudah $=3$ butir dan sedang $=$ 2 butir perbaikan nilai rata-rata refleksi awal sebesar 60,22 menjadi nilai rata-rata siklus I sebesar 70,30 ini sudah diatas KKM = 70. Hal ini dimungkinkan karena menurut pengakuan para peserta didik, guru jarang menggunakan media pembelajaran atau monoton dalam mengajar yaitu selalu menggunakan metode 
ceramah. Jadi, refleksinya harus memperbaiki RPP siklus II.

\section{B. Pembahasan Hasil Penelitian Siklus II}

a. Kualitas Pembelajaran

Perbaikan proses pembelajaran dilakukan dengan memperhatikan refleksi siklus I,terutama dalam kegiatan awal tentang apersepsi, mengoreksi pekerjaan rumah, dan mengaitkan materi dengan dunia kehidupan peserta didik. Selain itu, mengubah gaya pembelajaran juga lebih menekankan pada pembelajaran interaktifmelalui kelompok belajar, dan membimbing peserta didik berdiskusi kelompok setelah berhasil mengurutkan gambar. Ternyata ada peningkatan kualitas praktik pembelajaran sebesar 80,00\% dengan katagori berkualitas.

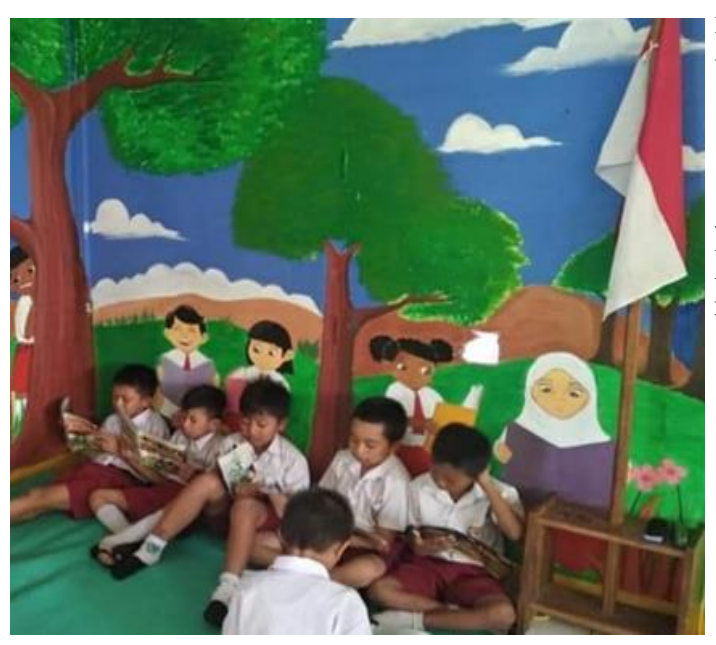

Gambar 3. Guru Membimbing peserta didik Menggali Pemahaman Materi

\section{b. Motivasi Belajar dan Keaktifan Peserta Didik}

Pencapaian motivasi belajarpeserta didikpada siklus II sebesar 82,61 \% lebih besar dari siklus I 71,48 \%. Perbaikan/peningkatan menunjukan bahwa perbaikan tampilan peneliti (performance) dan sikap peserta didik semakin berdampak positif terhadap keaktifan belajar. Peningkatan keaktifan belajar ini banyakdipengaruhi oleh sikap berani peserta didik, baik dalam diskusi saat dalam kelompok maupun individu, serta individu semakin aktif berlatih mengerjakan soal dibawah bimbingan peneliti.

Data keaktifan peserta didik siklus II dari dua kolaborator diperoleh hasil penelitian keaktifan peserta didikyang tidak jauh berbeda, sehingga hasil rata-rata sebesar $72,00 \%$ dengan katagori aktif/baik.

\section{c. Hasil Belajar Peserta Didik}

Hasil belajar siklus II sebesar 82,61\% meningkat dari hasil belajar siklus I sebesar $78,26 \%$. Secara kualitatif, ketiga aspek tersebut selalu berhubungan atau berpengaruh secara positif, terbukti dari hasil pencapaian masingmasing aspek.

Sedangkan analisis butir soal menghasilkan perbandingan mudah $=2$ butir dan sedang $=3$ butir, sehingga cukup menarik untuk meneliti lebih lanjut, artinya penerapan model pembelajaran Mind Mappingefektif untuk meningkatkan hasil belajar peserta didik.

\section{Pembahasan Hasil Penelitian Siklus III}

Ketiga aspek yang diteliti mulai siklus I hingga siklus III meningkat atau terjadi perbaikan peningkatan secara berkesinambungan dan teratur, begitu juga siklus III dengan hasil sangat berarti.

a. Kualitas pembelajaran

Kualitas seorang pendidik professional dipengaruhi oleh faktor tingkat kualifikasi akademik dan pengalaman mengajar, serta mengikuti pendidikan dan latihan (diklat). Syarat utama pendidik sebagai agen pembelajaran, sebagaimana tercantum pada UU Nomor 14 tahun 2005 tentang guru dan dosen, minimal memiliki 4 (empat) kompetensi, yaitu (1) kompetensi paedagogik, (2) kompetensi kepribadian, (3) kompetensi professional, (4) kompetensi sosial.

Berpedoman pada prinsip-prinsip kualitas pembelajaran mulai dari siklus I dan II, ternyata pada siklus III berhasil mencapai kualitas pembelajaran sebesar $86,54 \%$ yang melampaui indikator yang ditetapkan.

b. Motivasi Belajar dan Keaktifan Peserta Didik

Departemen pendidikan dan kebudayaan memuat pendapat bahwa ada beberapa bentuk 
pembelajaran yang memotivasi belajar peserta didik, antara lain:

1) Buat pembelajaran penuh arti.

2) Ciptakan hubungan yang hangat dengan peserta didik

3) Terapkan model pembelajaran yang inovatif.

4) Kembangkan pendidikan sistem among, guru berperan sebagai fasilitator, motivator dan tutwuri handayani.

5) Salurkan minat dan kegemaran peserta didik dalam berbagai kegiatan.

6) Bentuklah kelompok-kelompok belajar.

Perubahan peningkatan keaktifan belajar peserta didik terjadi peningkatan yang signifikan. Keaktifan di observasi secara langsung dengan menggunakan lembar observasi kegiatan peserta didik dimana hasil keaktifan peserta didik pada siklus I sebesar $61,00 \%$, siklus II sebesar $72,00 \%$, dan siklus III sebesar $82,00 \%$ atau rata-rata sebesar $71,67 \%$ yang berarti katagori baik.

\section{c. Hasil Belajar Peserta Didik}

Hasil belajar ditentukan oleh gabungan antara kemampuan dasar kesungguhan dalam belajar. Kesungguhan ditentukan oleh motivasi yang bersangkutan. Maka sangatlah penting menumbuhkan motivasi belajar untuk mencapai hasil belajar.

Berdasarkan profil peserta didik kelas IV SD NegeriCiater 03 dalam proses dan penilaian hasil belajar dilakukan dengan gaya kognitif, yaitu gaya dari tiap-tiap peserta didik yang bersifat relatif stabil dan menjadi kebiasaaan individu-individu tersebut.

Pendekatan gaya kognitif pada penilaian hasil belajar memperoleh hasil siklus I sebesar $78,26 \%$, siklus II sebesar $82,61 \%$, siklus III sebesar 91,30\%. Penerapan model pembelajaran Mind Mappingberhasil dan ditemukan2 orang peserta didik yang berkompetensi lemah. Adapun tingkat kesukaran soal siklus III adalah mudah $=3$ butir dan sedang $=2$ butir.Hasil rata-rata setiap sub materi siklus $\mathrm{I}=70,30$ siklus $\mathrm{II}=76,91$, siklus III $=80,22$ semua diatas $\mathrm{KKM}=70$, artinya penelitian melalui model pembelajaran Mind Mappingberhasil.

\section{SIMPULAN DAN SARAN}

Berdasarkan hasil analisis data penelitian tindakan kelas yang telah dilaksanakan pada peserta didik kelas IV SD Negeri Ciater 03 Tangerang Selatan ditarik kesimpulan bahwa penerapan model pembelajaran Mind Mapping dapat meningkatkan hasil belajar pada mata pelajaran IPA materi Tumbuhan dan Hewan di Lingkungan Rumahku beserta fungsinya.

Kesimpulan ini diperkuat dengan hasil sebagai berikut:

1. Perbaikan siklus pembelajaran pada siklus I sebesar 76,54\%, siklus II sebesar $80,00 \%$, siklus III sebesar $86,54 \%$, artinya perbaikan proses pembelajaran secara bermakna.

2. Perbaikan motivasi belajar dari siklus I sebesar 71,48\%, siklus II sebesar $82,61 \%$, Siklus III sebesar 87,04 \%, sedangkan perbaikan keaktifan peserta didik dari siklus I sebesar $61,00 \%$, siklus II sebesar $72,00 \%$, siklus III sebesar $82,00 \%$, terjadi perbaikan dan peningkatan motivasi belajar dan keaktifan belajar peserta didik pada mata pelajaran IPA menjadi sangat baik.

3. Ketuntasan belajar dari pra siklus sebesar $30,43 \%$, siklus I sebesar $78,26 \%$, siklus II sebesar $82,61 \%$, siklus III sebesar $91,30 \%$, data ini menunjukkan terjadi perbaikan yang sangat bermakna sebagai inti dari penelitian tindakan kelas.

4. Hasil belajar IPA terjadi peningkatan yaitu pada siklus $\mathrm{I}=70,30$; siklus II $=$ 77,91; dan siklus III $=80,09$. Data ini menunjukkan peningkatan rata-rata tes IPA yang signifikan pada setiap siklus.

\section{DAFTAR PUSTAKA}

Aji, S. (2016). Keefektifan Penggunaan Model Pembelajaran Kumon Dengan Teknik Peta Konsep (Mind Mapping) Terhadap Hasil Belajar Pada Siswa Kelas X Akuntansi Smk 2 Wonosobo 
(Kompetensi Dasar Jurnal

Penyesuaian) (Doctoral dissertation,

Universitas Negeri Semarang).

Apriani, N., Ayub, S., \& Hikmawati, H. (2016). pengaruh model pembelajaran berbasis masalah terhadap hasil belajar fisika siswa kelas $\mathrm{x}$ sman 2 praya tahun pelajaran 2015/2016. Jurnal Pijar Mipa, 11(2).

Fadillah, A. (2015). Pengaruh model pembelajaran dan kemampuan komunikasi matematika terhadap hasil belajar matematika siswa. FIBONACCI: Jurnal Pendidikan Matematika dan Matematika, 1(2), 1-12.

Saputri, L. K., \& Sungkono, J. (2019). Upaya Peningkatan Keaktifan dan Hasil Belajar Matematika Menggunakan Metode Mind map pada Siswa Kelas VII SMP Negeri 2 Trucuk. ABSIS: Mathematics Education Journal, 1(1).

Slameto. 2003. Belajar dan Faktor-faktor yang Mempengaruhinya. Jakarta: Rineka Cipta.

Suwardi, S., Firmiana, M. E., \& Rohayati, R. (2016). Pengaruh Penggunaan Alat Peraga terhadap Hasil Pembelajaran Matematika pada Anak Usia Dini. Jurnal Al-Azhar Indonesia Seri Humaniora, 2(4), 297-305. 